\title{
Association between leukocyte telomere shortening and exposure to traffic pollution: a cross-sectional study on traffic officers and indoor office workers
}

\author{
Mirjam Hoxha ${ }^{1,2}$, Laura Dioni ${ }^{1,2}$, Matteo Bonzini ${ }^{3}$, Angela Cecilia Pesatori ${ }^{2,4}$, \\ Silvia Fustinoni ${ }^{5}$, Domenico Cavallo ${ }^{6}$, Michele Carugno ${ }^{1,2}$, \\ Benedetta Albetti1,2, Barbara Marinelli1,2, Joel Schwartz ${ }^{7}$, \\ Pier Alberto Bertazzi ${ }^{2,4}$ and Andrea Baccarelli*1,2,7
}

Address: ${ }^{1}$ Center of Molecular and Genetic Epidemiology, Department of Preventive Medicine, IRCCS Maggiore Hospital, Mangiagalli and Regina Elena Foundation, Milan, Italy, ${ }^{2}$ Department of Environmental and Occupational Health, Università degli Studi di Milano, Milan, Italy, ${ }^{3}$ Department of Clinical and Biological Sciences, University of Insubria, Varese, Italy, ${ }^{4}$ Epidemiology Unit, Department of Preventive Medicine, IRCCS Maggiore Hospital, Mangiagalli and Regina Elena Foundation, Milan, Italy, ${ }^{5}$ Toxicology Unit, Department of Environmental and Occupational Health, IRCCS Maggiore Hospital, Mangiagalli and Regina Elena Foundation, Milan, Italy, ${ }^{6}$ Department of Chemistry and Environmental Sciences, University of Insubria, Como, Italy and ${ }^{7}$ Exposure, Epidemiology and Risk Program, Department of Environmental Health, Harvard School of Public Health, 401 Park Drive, Landmark Center, Suite 415 West, Boston, MA 02215, USA

Email: Mirjam Hoxha - mirjam.hoxha@unimi.it; Laura Dioni - laura.dioni@unimi.it; Matteo Bonzini - matteo.bonzini@infinito.it; Angela Cecilia Pesatori - angela.pesatori@unimi.it; Silvia Fustinoni - silvia.fustinoni@unimi.it;

Domenico Cavallo - domenico.cavallo@unimi.it; Michele Carugno - michele.carugno@gmail.com;

Benedetta Albetti - benedetta.albetti@unimi.it; Barbara Marinelli - barbara.marinelli@unimi.it; Joel Schwartz - joel@hsph.harvard.edu;

Pier Alberto Bertazzi - pieralberto.bertazzi@unimi.it; Andrea Baccarelli* - andrea.baccarelli@unimi.it

* Corresponding author

Published: 21 September 2009

Environmental Health 2009, 8:4I doi:I0.II86/1476-069X-8-4I
Received: 10 February 2009

Accepted: 2I September 2009

This article is available from: http://www.ehjournal.net/content/8/I/4I

(C) 2009 Hoxha et al; licensee BioMed Central Ltd.

This is an Open Access article distributed under the terms of the Creative Commons Attribution License (http://creativecommons.org/licenses/by/2.0), which permits unrestricted use, distribution, and reproduction in any medium, provided the original work is properly cited.

\begin{abstract}
Background: Telomere shortening in blood leukocytes has been associated with increased morbidity and death from cardiovascular disease and cancer, but determinants of shortened telomeres, a molecular feature of biological aging, are still largely unidentified. Traffic pollution has been linked with both cardiovascular and cancer risks, particularly in older subjects. Whether exposure to traffic pollution is associated with telomere shortening has never been evaluated.
\end{abstract}

Methods: We measured leukocyte telomere length (LTL) by real-time PCR in blood DNA from 77 traffic officers exposed to high levels of traffic pollutants and 57 office workers (referents). Airborne benzene and toluene, as tracers for traffic exposure, were measured using personal passive samplers and gas-chromatography/flame-ionization detector analysis. We used covariateadjusted multivariable models to test the effects of the exposure on LTL and obtain adjusted LTL means and 95\% Confidence Intervals (Cls).

Results: Adjusted mean LTL was I.I0 $(95 \% \mathrm{Cl}$ I.04-I.16) in traffic officers and 1.27 in referents $(95 \% \mathrm{Cl}$ I.20-I.35) $[\mathrm{p}<0.00 \mathrm{I}]$. LTL decreased in association with age in both traffic officers ( $\mathrm{p}=$ $0.01)$ and referents $(p=0.001)$, but traffic officers had shorter LTL within each age category. Among traffic officers, adjusted mean relative LTL was shorter in individuals working in high $(\mathrm{n}=$ $45, \mathrm{LTL}=1.02,95 \% \mathrm{Cl} 0.96-1.09)$ compared to low traffic intensity $(n=32, \mathrm{LTL}=1.22,95 \% \mathrm{Cl}$ I.13- 
I.3I) $[\mathrm{P}<0.00 \mathrm{I}]$. In the entire study population, LTL decreased with increasing levels of personal exposure to benzene $(p=0.004)$ and toluene $(p=0.008)$.

Conclusion: Our results indicate that leukocyte telomere length is shortened in subjects exposed to traffic pollution, suggesting evidence of early biological aging and disease risk.

\section{Background}

Telomeres are repetitive sequence nucleotides (TTAGGG)n positioned at the end of chromosomes that protect extremities from nucleolytic degradation and maintain chromosomal structural integrity [1]. Telomeres are widely regarded as the internal biological clock of a living organism, as their length shortens with age in all replicating somatic cells that have been examined [2-5]. Critically short telomeres are assumed to have functional implications, such as the induction of cellular senescence, which is characterized by the expression of specific markers of aging and the inability of the cell to divide further [2]. Features of biological aging vary considerably among individuals, and such differences may reflect a variety of environmental factors that affect oxidative stress and inflammation and, consequently, accelerate telomere shortening $[2,6,7]$. In human studies, telomere length measured in leukocyte DNA decreases with age $[8,9]$, and telomere attrition in blood leukocytes has been shown to be accelerated by environmental factors that enhance biological aging, such as smoking [4] and oxidative stress [10]. Epidemiological investigations have demonstrated that individuals with shorter telomere length in circulating leukocytes have decreased life-expectancy $[8,9,11]$, and increased risk of myocardial infarction $[12,13]$, severe coronary heart disease [14], heart failure [15], hypertension [16], stroke [13], and cancer [17].

Pollution from traffic emissions, a major contributor of air pollutant exposure in urban areas, has been related to premature morbidity and mortality from cardiovascular disease and cancer in several epidemiological studies [1821]. Exposure to traffic pollutants has been linked with activation of biological processes, such as production of Reactive Oxygen Species (ROS) $[22,23]$ and activation of inflammatory pathways $[24,25]$, which have been related to accelerated telomere shortening $[2,4]$.

Whether exposure to traffic pollution is related with telomere shortening has never been determined. In the present work, we evaluated the effects of traffic pollution on telomere length measured in blood leukocytes of healthy subjects with different levels of exposure to traffic.

\section{Methods}

Study Participants and Exposure Assessment

The study included 77 street traffic officers and 57 office workers (referents) examined in Milan, Italy, between
October 1999 and June 2000 (Table 1). At the time of examination, all study participants had been employed for at least one year. The traffic officers were assigned to full time traffic duties in inner-city Milan (7-hour shifts from $6: 30$ am to $1: 30 \mathrm{pm}$ ), and did not include motorcycling or car patrol officers. Individual written informed consent was obtained from all participants before the study. The study was approved by the Institutional Review Board of the Maggiore Hospital Foundation, Milan, Italy. A structured questionnaire was used to collect information on lifestyle, and risk factors. Traffic officers were also asked to evaluate the usual traffic conditions during their work shifts by a specific questionnaire item that gave two possible choices (low traffic or high traffic). None of the subjects had acute inflammatory conditions or other concurrent illnesses, as shown by responses to specific questionnaire items, as well as by no major abnormalities in differential blood counts.

Airborne benzene and toluene, taken as tracers of traffic exposure [26], were measured by a passive sampler (stainless steel tube, $9 \mathrm{~mm}$ diameter $\times 90 \mathrm{~mm}$ length; containing Chromosorb 106) worn near the breathing zone by each participant for one entire work shift. Passive sampling allows to obtain an integrated measure of the airborne pollutant levels over the entire time period the sampler is worn. Benzene and toluene concentrations were determined by thermal desorption followed by gas chromatography/flame-ionization detector analysis. None of the study subjects was exposed during the monitoring period to sources of benzene or toluene other than traffic pollution such as paints, glues, adhesives, varnishes, lacquers, or shoe polishes. The day following work shift in which airborne benzene and toluene exposure was assessed, a $7 \mathrm{ml}$ whole blood sample was collected in EDTA tube. All samples were collected at 8:30 AM.

\section{Telomere length measurement}

DNA was extracted from whole blood using the Nucleon ${ }^{\mathrm{TM}}$ BACC2 genomic DNA extraction kit (Amersham). Leukocyte Telomere Length (LTL) was measured in blood genomic DNA using the quantitative real-time method described by Cawthon [27], which measures the relative LTL by determining the ratio of telomere repeat copy number $(\mathrm{T})$ to single copy gene $(\mathrm{S})$ copy number $(\mathrm{T} / \mathrm{S}$ ratio) in experimental samples relative to a reference sample. DNA samples from referents and traffic officers were interspersed across PCR plates. 
Table I: General characteristics of the study subjects

\begin{tabular}{|c|c|c|c|}
\hline & $\begin{array}{l}\text { Referents } \\
(n=57)\end{array}$ & $\begin{array}{l}\text { Traffic officers } \\
(n=77)\end{array}$ & p-value ${ }^{a}$ \\
\hline \multicolumn{4}{|l|}{ Age, n (\%) } \\
\hline$<30$ years & $16(28 \%)$ & $36(47 \%)$ & \\
\hline $30-40$ years & $19(33 \%)$ & 31 (40\%) & \\
\hline$>40$ years & 22 (39\%) & $10(13 \%)$ & 0.002 \\
\hline \multicolumn{4}{|l|}{ Gender, n (\%) } \\
\hline Male & 38 (67\%) & 47 (61\%) & \\
\hline Female & $19(33 \%)$ & 30 (39\%) & 0.58 \\
\hline \multicolumn{4}{|c|}{ Cigarette smoking, n (\%) } \\
\hline Never & $26(46 \%)$ & 40 (52\%) & \\
\hline Ever & 31 (54\%) & 37 (48\%) & 0.49 \\
\hline
\end{tabular}

Cigarettes/day, n (\%)

\begin{tabular}{llll}
\hline I-10 cigarettes/day & $9(40 \%)$ & $5(18 \%)$ & \\
\hline 1 I-20 cigarettes/day & $7(30 \%)$ & $16(57 \%)$ & \\
\hline$>20$ cigarettes/day & $7(30 \%)$ & $7(25 \%)$ & 0.15 \\
\hline
\end{tabular}

Pack-years of smoking, n (\%)

\begin{tabular}{cccc}
\hline 0 pack-years & $26(45 \%)$ & $40(52 \%)$ & \\
\hline $0.1-10$ pack-years & $14(25 \%)$ & $22(28 \%)$ & \\
\hline$>10$ pack-years & $17(30 \%)$ & $15(20 \%)$ & 0.39 \\
\hline
\end{tabular}

Exposure to environmental tobacco smoke, $n(\%)^{c}$

\begin{tabular}{cccc}
\hline No & $14(54 \%)$ & $24(60 \%)$ & \\
\hline Yes & $12(46 \%)$ & $16(40 \%)$ & 0.30 \\
\hline
\end{tabular}

Alcohol consumption, $\mathrm{n}(\%)^{\mathrm{d}}$

\begin{tabular}{llll}
\hline Occasional/never & $24(44 \%)$ & $40(56 \%)$ & \\
\hline Every week & $14(26 \%)$ & $18(26 \%)$ & \\
\hline Every day & $16(30 \%)$ & $13(18 \%)$ & 0.27 \\
\hline
\end{tabular}

aFisher exact test for differences across categories

bData for current smokers are shown

cData for never smokers are shown

dSubject count not add up to the total number of participants due to missing values
The T (telomere) PCR mix was: iQ SYBR Green Supermix (Bio-Rad) 1×, tel1b $100 \mathrm{nM}$, tel2b $900 \mathrm{nM}$, DMSO 1\%, EDTA $1 \times$. The S (human beta-globin) PCR mix was: iQ SYBR Green Supermix (Bio-Rad) 1×, hbg1 $300 \mathrm{nM}$, hbg2 $700 \mathrm{nM}$, DMSO 1\%, DTT 2,5 mM, EDTA $1 \times$. We used the PCR primer sets previously described by Mc Grath et al. [28]. We used pooled DNA from 20 referents (500 ng for each sample), randomly selected from samples of this same study, to create a fresh standard curve, ranging from $8 \mathrm{ng} / \mu \mathrm{l}$ to $0,5 \mathrm{ng} / \mu \mathrm{l}$, at every T and S PCR run. All samples contained E. coli DNA heated at $96^{\circ} \mathrm{C} \times 10$ minutes and cooled at room temperature. 15 ng of DNA samples was added to each reaction (final volume $20 \mu \mathrm{l}$ ). All PCRs were performed on a DNA Engine thermal cycler Chromo4 (Bio-Rad, Hercules, California, USA). The thermal cycling profile for both amplicons started with a $95^{\circ} \mathrm{C}$ incubation for 3 minutes to activate the hot-start iTaq DNA polymerase. The T PCR continued with 25 cycles at $95^{\circ} \mathrm{C}$ for $15 \mathrm{~s}$, and anneal/extend at $54^{\circ} \mathrm{C}$ for $49 \mathrm{~s}$. The S PCR continued with 35 cycles at $95^{\circ} \mathrm{C}$ for $15 \mathrm{~s}$, anneal at $58^{\circ} \mathrm{C}$ for $1 \mathrm{~s}$, extend at $72^{\circ} \mathrm{C}$ for $15 \mathrm{~s}$. At the end of each reaction, a melting curve was used for both $\mathrm{T}$ and S PCRs. All samples were run in triplicates and the mean of three measurements was used in the statistical analyses.

\section{Statistical Analysis}

Telomere length was log-transformed to approximate normal distribution. Consequently, we present telomere length data as geometric means and 95\% Confidence Intervals (CIs). In univariate analysis, we used the Fisher's exact test to evaluate the association of telomere length with individual characteristics, which were all presented as categorical variables. As traffic officers and referents differed in their age distribution, we tested for differences in telomere length between the two groups using regression models that adjusted for age (fitted as a continuous variable), in addition to gender, and smoking (ever/never), and pack years of smoking. We used multivariable regression models adjusting for the same variables (fitted as a continuous variable) also to evaluate the association of benzene or toluene with telomere length. As a sensitivity analysis, we fitted a set of models that included a quadratic term for age in addition to the linear term. Result from this set of models showed only marginal differences from the results reported in the paper. All statistical tests were two-sided. A p-value $<0.05$ was considered statistically significant. All analyses were performed in Stata 9.0 (Stata Corp., College Station, TX).

\section{Results \\ Characteristics of the Study Population and Personal Exposure to Airborne Traffic Pollutants}

The characteristics of the study subjects are shown in Table 1 . Traffic officers were moderately but significantly younger than referents $(p=0.002)$. The two groups were 
otherwise similar for the other characteristics that we considered. Mean airborne benzene levels, measured by personal breathing zone samplers during the entire work shift, were $13.0 \mu \mathrm{g} / \mathrm{m}^{3}$ (95\% CI 8.2-17.9) in referents and $31.8 \mu \mathrm{g} / \mathrm{m}^{3}$ (95\% CI 22.6-40.9) in traffic officers (Table 2). Mean airborne toluene levels were $43.4 \mu \mathrm{g} / \mathrm{m}^{3}(95 \%$ CI 30.5-56.2) in referents and $128.7 \mu \mathrm{g} / \mathrm{m}^{3}$ (95\% CI 73.5183.9) in traffic officers (Table 2). Airborne benzene and toluene levels were highly correlated in this study population $\left(\mathrm{r}^{2}=0.87\right)$. Among traffic officers, 32 individuals reported to be usually exposed to low traffic intensity, and 45 to high traffic intensity. Individuals reporting exposure to low traffic intensity had mean airborne benzene of 26.3 $\mu \mathrm{g} / \mathrm{m}^{3}$ (95\% CI 19.9-32.6) and mean airborne toluene of $101.1 \mu \mathrm{g} / \mathrm{m}^{3}$ (95\% CI 66.8-137.0), whereas individuals reporting exposure to high traffic intensity had mean airborne benzene of $35.7 \mu \mathrm{g} / \mathrm{m}^{3}$ (95\% CI 20.6-50.8) and mean airborne toluene of $147.8 \mu \mathrm{g} / \mathrm{m}^{3}$ (95\% CI 55.3 240.8).

\section{Telomere length and individual characteristics}

LTL decreased significantly in association with age in both referents $(\mathrm{p}=0.001)$ and traffic officers $(\mathrm{p}=0.01)$ [Table $3]$. In each age category, traffic officers exhibited shorter telomeres than referents. Gender was not associated with LTL either in referents or traffic officers. Among referents, LTL was shorter in ever smokers $(p=0.04)$, particularly in those with a higher number of pack-years of smoking $(\mathrm{p}=$ 0.05). The relationship between smoking habits (ever/ never) and telomere length was borderline significant after adjusting by age ( $\mathrm{p}=0.06)$, while the effect of packyears was not statistically significant $(\mathrm{p}=0.16)$ [Table 3]. Among traffic officers, smoking and pack-years were not statistically associated with LTL (Table 3). Mean relative LTL was not associated with number of cigarettes/day, exposure to environmental tobacco smoke, or alcohol consumption, either in referents or traffic officers (Table 3). In addition, we evaluated whether LTL was associated with results from complete blood counts. LTL was not associated in traffic officers or referents with white blood cell count, or proportions of neutrophils, lymphocytes, monocytes, basophils, and eosinophils (data not shown).

\section{Telomere length and traffic exposure}

Mean relative LTL, estimated in models adjusting for age, gender, smoking (ever/never), and pack-years, was shorter in traffic officers (mean $=1.10,95 \%$ CI 1.04-1.16) than in referents $($ mean $=1.27,95 \%$ CI 1.20-1.35) $[\mathrm{p}<0.001$, Figure $1 \mathrm{~A}$ ]. Among traffic officers [Figure 1B], relative LTL was shorter in individuals working in high traffic intensity (mean $=1.02,95 \%$ CI $0.96-1.09)$ compared to those working in low traffic intensity (mean $=1.22,95 \% \mathrm{CI}$ 1.13-1.31) [p < 0.001]. LTL in traffic officers working in low traffic intensity was not significantly shorter than in referents.

We found no association between duration of employment and LTL. Among traffic officers, individuals with shorter duration of employment ( $1-2$ years, $n=48)$ had adjusted mean LTL of 1.09 (95\% CI 1.01-1.17), whereas individuals with longer employment (3-17 years) had adjusted mean LTL of 1.11 (95\% CI 1.03-1.21) [p=0.62].

\section{Telomere length and levels of traffic pollutants}

LTL decreased in association with increasing personal levels of airborne benzene (Figure 2A) and toluene (Figure 2B). In models adjusting for age, gender, smoking (ever/ never), and pack-years, we estimated that an increase in airborne benzene exposure level equal to the difference between the $25^{\text {th }}$ and $75^{\text {th }}$ centile (interquartile difference $\left.=11.2 \mu \mathrm{g} / \mathrm{m}^{3}\right)$ was associated with a $6.4 \%(95 \% \mathrm{CI}, 2.1 \%$ $10.4 \%)$ decrease in LTL $(\mathrm{p}=0.004)$. An increase in airborne toluene exposure level equal to the difference between the $25^{\text {th }}$ and $75^{\text {th }}$ centile (interquartile difference $\left.=25.7 \mu \mathrm{g} / \mathrm{m}^{3}\right)$ was associated with a $6.2 \%(95 \%$ CI $1.7 \%$ $10.4 \%)$ decrease in LTL $(\mathrm{p}=0.008)$. To get a perception of the magnitude of benzene and toluene effects, LTL decreases associated with the exposures can be compared to the percent decrease in LTL associated with age. Among the referent subjects, each year of age was associated with a $0.5 \%$ (95\% CI 0.1\%-0.9\%) decrease in LTL. As a sensitivity analysis, we tested for the association of benzene and toluene with LTL after excluding the two study participants with the highest levels of exposure. In this analysis, the effects of benzene and toluene remained statistically significant $(6.1 \%, 95 \%$ CI 1.5\%-10.4\%, $\mathrm{p}=0.01$ for ben-

Table 2: Personal exposure levela to airborne benzene and toluene in indoor office workers (referents) and traffic officers

\begin{tabular}{lcccccc}
\hline & & $\begin{array}{c}\text { Referents } \\
(\mathbf{n}=\mathbf{5 7})\end{array}$ & & & \multicolumn{2}{c}{$\begin{array}{c}\text { Traffic officers } \\
(\mathbf{n}=\mathbf{7 7})\end{array}$} \\
\hline & Mean & $\mathbf{( 9 5 \% ~ C l )}$ & Min/Max & Mean & $(\mathbf{9 5 \%} \mathbf{C l})$ & $\mathbf{M i n} / \mathbf{M a x}$ \\
\hline Benzene, $\mu \mathrm{g} / \mathrm{m}^{3}$ & 13.0 & $\begin{array}{c}(8.2-17.9) \\
(30.5-56.2)\end{array}$ & $\begin{array}{c}2.0 / 115.1 \\
6.0 / 368.0\end{array}$ & $\begin{array}{c}31.8 \\
128.7\end{array}$ & $\begin{array}{c}(22.6-40.9) \\
(73.5-183.9)\end{array}$ & $\begin{array}{c}9.0 / 315.7 \\
24.4 / 1710.7\end{array}$ \\
\hline
\end{tabular}

aAirborne benzene and toluene concentrations measured as a tracer of traffic exposure measured through a passive sampler worn near the breathing zone by each participant during work shift. Airborne benzene and toluene levels showed high correlation in this study population $\left(r^{2}=0.87\right)$ 
Table 3: Telomere length by individual characteristics of indoor office workers (referents) and traffic officers

\begin{tabular}{|c|c|c|c|c|c|c|c|c|c|c|}
\hline & \multicolumn{5}{|c|}{ Referents $(n=57)$} & \multicolumn{5}{|c|}{ Traffic officers $(n=77)$} \\
\hline & $\mathbf{n}$ & mean $^{a}$ & $(95 \% \mathrm{Cl})^{a}$ & p-value ${ }^{b}$ & p-valuec & $\mathbf{n}$ & mean $^{a}$ & $(95 \% \mathrm{Cl})^{a}$ & p-valueb & p-value \\
\hline \multicolumn{11}{|l|}{ Age } \\
\hline$<30$ year & 16 & 1.44 & $(1.31-1.59)$ & & & 36 & 1.22 & $(1.11-1.33)$ & & \\
\hline $30-40$ year & 19 & 1.21 & $(1.09-1.33)$ & & & 31 & 1.04 & $(0.98-1.11)$ & & \\
\hline$>40$ year & 22 & 1.14 & $(1.03-1.26)$ & 0.001 & - & 10 & 1.03 & $(0.91-1.17)$ & 0.01 & - \\
\hline \multicolumn{11}{|l|}{ Gender } \\
\hline Male & 38 & 1.24 & $(1.15-1.34)$ & & & 47 & 1.12 & $(1.04-1.20)$ & & \\
\hline Female & 19 & 1.23 & $(1.10-1.38)$ & 0.90 & 0.74 & 30 & 1.12 & $(1.04-1.22)$ & 0.91 & 0.71 \\
\hline \multicolumn{11}{|l|}{ Cigarette smoking } \\
\hline Never smokers & 26 & 1.33 & $(1.20-1.48)$ & & & 40 & 1.16 & $(1.07-1.26)$ & & \\
\hline Ever smokers & 31 & 1.17 & $(1.10-1.25)$ & 0.04 & 0.06 & 37 & 1.08 & $(1.01-1.15)$ & 0.17 & 0.33 \\
\hline \multicolumn{11}{|l|}{ Cigarettes/dayd } \\
\hline I-I 0 cig./day & 9 & 1.19 & $(1.03-1.37)$ & & & 5 & 1.27 & $(0.94-1.73)$ & & \\
\hline II-20 cig./day & 7 & 1.20 & $(1.05-1.38)$ & & & 16 & 1.05 & $(0.96-1.14)$ & & \\
\hline$>20$ cig./day & 7 & 1.19 & $(0.96-I .47)$ & 0.99 & 0.47 & 7 & 1.09 & $(0.98-1.22)$ & 0.22 & 0.38 \\
\hline
\end{tabular}

Pack-years

\begin{tabular}{|c|c|c|c|c|c|c|c|c|c|c|}
\hline 0 pack-years & 26 & 1.33 & $(1.20-1.48)$ & & & 40 & 1.15 & $(1.06-1.25)$ & & \\
\hline $0.1-10$ pack-years & 14 & 1.19 & $(1.07-1.32)$ & & & 22 & 1.11 & $(1.00-1.23)$ & & \\
\hline$>10$ pack-years & 17 & 1.16 & $(1.05-1.28)$ & 0.05 & 0.16 & 15 & 1.05 & $(0.97-1.14)$ & 0.18 & 0.43 \\
\hline
\end{tabular}

Exposure to environmental tobacco smoke

\begin{tabular}{|c|c|c|c|c|c|c|c|c|c|c|}
\hline No & 14 & 1.27 & $(1.10-1.46)$ & & & 24 & 1.18 & $(1.06-1.31)$ & & \\
\hline Yes & 12 & 1.40 & $(1.17-1.68)$ & 0.26 & 0.39 & 16 & 1.12 & $(0.98-1.30)$ & 0.59 & 0.31 \\
\hline \multicolumn{11}{|c|}{ Alcohol consumption, $n(\%)^{f}$} \\
\hline Occasional/never & 24 & 1.26 & $(1.15-1.37)$ & & & 40 & 1.20 & $(1.11-1.28)$ & & \\
\hline Every week & 14 & 1.28 & $(1.16-1.39)$ & & & 18 & 1.15 & $(0.96-1.35)$ & & \\
\hline Every day & 16 & 1.24 & $(1.04-1.46)$ & 0.93 & 0.27 & 13 & 1.05 & $(0.97-1.13)$ & 0.13 & 0.41 \\
\hline
\end{tabular}

aStatistical analysis on telomere length were performed on log-transformed data to approximate normal distribution. Geometric means and $95 \%$ Confidence Intervals $(\mathrm{Cls})$ are reported

${ }_{\mathrm{b}} \mathrm{p}$-values from t-test (two-class variables) or regression-based test for trend (variables with three categories) for differences in telomere length by subjects' characteristics

'Age adjusted $\mathrm{p}$-values from regression-based test for trend for differences in telomere length by subjects characteristics. Age was fitted as a continuous variable in the models.

dData for current smokers are shown

eData for never smokers are shown

fSubject count not add up to the total number of participants due to missing values 

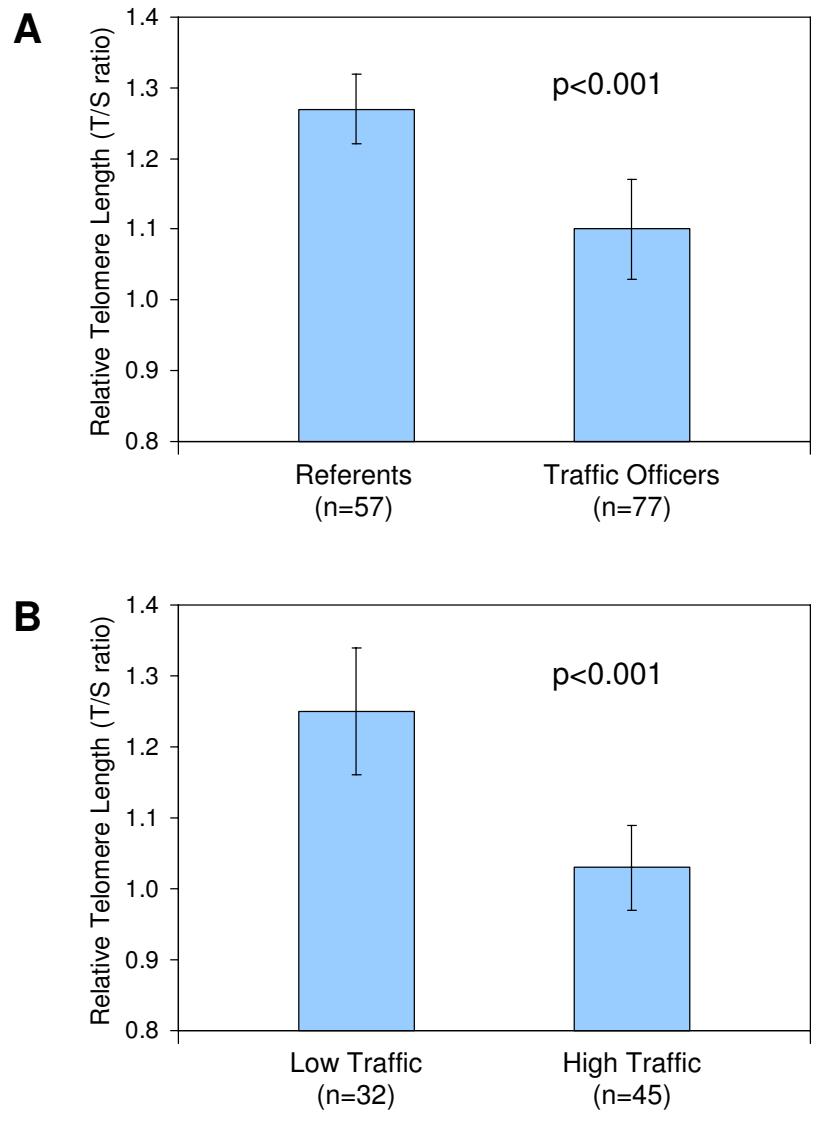

Figure I

Differences in leukocyte telomere length between (A) indoor office workers (referents) and traffic officers; and (B) traffic officers with exposure to low and high traffic intensity during their work shift. The graphs show geometric means (bars) $95 \%$ confidence intervals (lines) of telomere length adjusted by age, gender, smoking (ever/never), and pack-years.

zene, and 6.0\%, 95\% CI 1.0\%-10.7\%, p = 0.02 for toluene).

\section{Discussion}

Our findings indicate that exposure to widespread environmental pollutants, such as those from traffic emissions, may contribute to determine early biological aging, as chronicled by leukocyte telomere length. Traffic emissions are a mix of by-products of the combustion process including hundreds of pollutants in gaseous and particulate phases. Particles may stimulate directly the generation of ROS, or through transition metal and quinone structures that undergo redox cycling [29]. Other combustion products, including nitric oxide and benzene, have been shown to generate oxidative stress [30-32]. In addition, exposure to traffic pollutants may indirectly produce oxi-
A

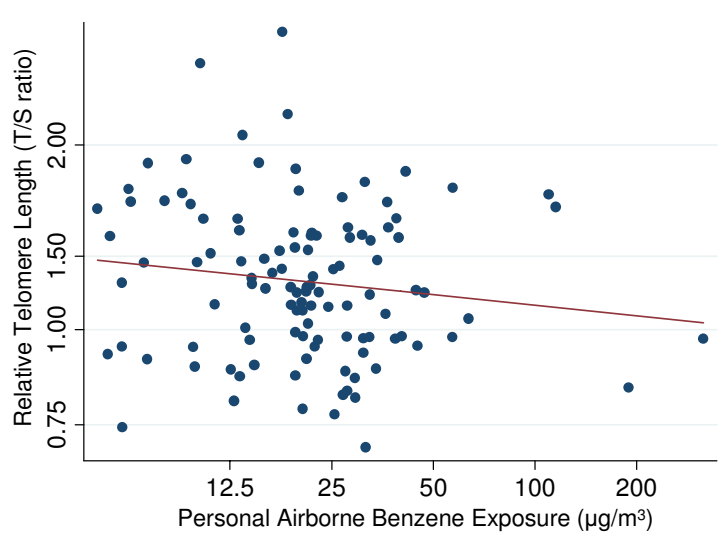

B

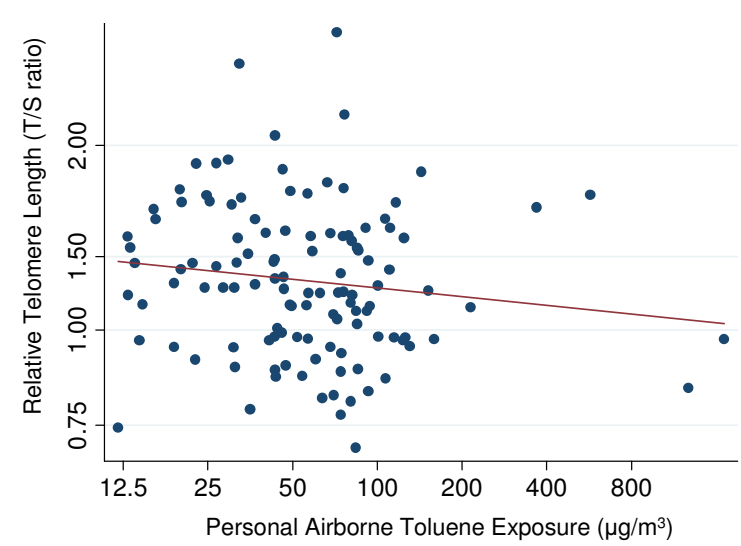

Figure 2

Decline of leukocyte telomere length associated with increasing levels of personal airborne of $(A)$ benzene $(p=0.004)$ and $(B)$ toluene $(p=0.008)$.

dative stress by activation of inflammatory cells capable of generating ROS and reactive nitrogen species [29]. Oxidative stress and inflammation, which have been shown to increase the rate of leukocyte telomere attrition [2-4,7,33], are widely considered as two main mediators of the effects of traffic pollutants on human health [22-24]. Oxidative stress can shorten telomeres in vitro, and antioxidants decrease shortening [34]. Due to their specific sequence with high guanine content, telomeres are remarkably sensitive to damage by oxidative stress [33]. In addition, telomeric DNA is deficient in the repair of single-strand breaks, which are induced by ROS either directly or as an intermediate step in the repair of oxidative base modifications [2]. Inflammatory processes cause heightened leukocyte turnover rate that can result in a greater loss of leukocyte telomere repeats over time $[2,4,33]$.

In our results, exposure to traffic appeared to anticipate the age-related decrease in telomere length. In particular, 
albeit telomere length was associated with age in both traffic officers and referents, when leukocyte telomere length was stratified by age (Table 3 ), traffic officers exhibited lengths that were similar to those observed in referents roughly ten years older. Similarly, an interquartile range change in quantitatively measured airborne benzene and toluene exposure was associated with a $6.4 \%$ and $6.2 \%$ decrease in LTL respectively, which was similar to that associated with a difference of 13 years in age, considering that a $0.5 \%$ decrease per each year of age in LTL was found in our study. Our data are based on a cross-sectional study, which does not provide direct information on dynamic changes in LTL over time. In addition our study did not have measures of long-term exposure to traffic pollutants. Future studies should prospectively address whether LTL decreases more rapidly in traffic exposed subjects as their age.

In addition, we found that smoking decreased blood telomere length, consistently with previous results [4]. In our study, ever smoking was associated with shorter telomeres among referent subjects, but we did not find an association with pack-years of smoking, cigarettes number, and exposure to environmental tobacco smoke possibly due to limited statistical power to test for such associations in our study. Also, the association between ever smoking and LTL was only borderline significant after adjustment by age.

Blood leukocytes have been used in several studies of telomere length that have related telomere shortening with smoking [4], as well as with myocardial infarction $[12,13]$, severe coronary heart disease [14], heart failure [15], hypertension [16], stroke [13], cancer [17], and decreased life-expectancy $[8,9,11]$. Rates of telomere shortening have been shown to be similar in different tissues, thus easily accessible tissues such as blood leukocytes may serve as surrogates for telomere length in tissues involved in age-related diseases [33].

The mechanisms linking shorter LTL with disease risk still need to be fully apprehended. Telomere shortening is universally accepted as a marker of individual and cellular aging $[5,7]$. Cellular senescence is a major feature of atherosclerotic plaques [35]. In in-vitro models, telomere shortening in coronary endothelial cells has been associated with expression of molecules implicated in atherogenesis [36]. Short telomeres have been also associated with increased genetic instability. Shortened telomeres lose their capping function at the end of chromosomes. Such dysfunctional telomeres can result in sister cromatid fusion and breakage/fusion/bridge leading to non reciprocal translocation and chromosomal rearrangement, commonly associated with human cancer [37].
Our study was based on a sample of traffic officers and indoor office workers with different degrees of exposure to traffic pollutants. We found shortened LTL in traffic officers, particularly in those working in high traffic conditions. In addition, we further characterized the exposure of the study participants using personal measures of airborne benzene and toluene, taken as tracers of traffic emissions [38]. In an Italian study conducted in the same years as our study that also included traffic officers [26], personal benzene exposure was shown be more tightly correlated with local traffic intensity than other measures of air pollution such as particulate matter of aerodynamic diameter $<10 \mu \mathrm{m}\left(\mathrm{PM}_{10}\right)$ measured by personal monitors.

In our study, the referent subjects were moderately older than the traffic officers. To account for this inequality, which would have decreased the observed difference in telomere length, we used multivariable analyses that adjusted our results by age, as well as by other potential confounders, including gender, smoking, and pack-years.

Our results, coupled with previous evidence showing that telomere length is associated with increased incidence of cardiovascular disease and cancer [12-17], lead us to speculate that shortened telomeres are an intermediate step between exposure to traffic pollutants and health-related effects. However, we cannot exclude that telomere length may just reflect (and thus serve as useful indicators of) the biological history of cells and individuals [8], without a mechanistic role in the development of exposure-related health outcomes. In addition, exposure to traffic noise might have contributed to determine shorter LTL in our exposed group. Noise exposure has also been shown to increase oxidative stress [39]. Because we did not collect any information on noise exposure in our study, we were unable to test whether traffic noise determined shorter LTL in our exposed group. Cherkas et al. [40] have found that LTL was longer in subjects who reported higher leisure-time physical activity. However, Cherkas et al. suggested that intermittent physical activity specifically in leisure-time has beneficial effects on LTL, because adjusting LTL for physical activity at work did not affect their results. In our study, we found shorter LTL in the exposed group was compared to a group of office worker referents, who might have more sedentary work. Although we did not collect information on work-related and leisure-time physical activities, we expect that differences in workrelated physical activities between the two exposure groups might have decreased, rather than caused, the differences in LTL we found in our study.

\section{Conclusion}

We showed that leukocyte telomere length is shortened in subjects exposed to traffic pollution, particularly in subjects exposed to intense traffic and with higher levels of 
personal exposure to airborne traffic pollutants. Our findings indicate that early biological aging, as reflected in telomere shortening, may mediate the effects of traffic exposure on human health.

\section{Abbreviations}

LTL: Leukocyte Telomere Length; 95\% CI: 95\% Confidence Interval; ROS: Reactive Oxygen Species.

\section{Competing interests}

The authors declare that they have no competing interests.

\section{Authors' contributions}

$\mathrm{ACP}, \mathrm{JS}, \mathrm{PAB}$, and $\mathrm{AB}$ designed research. $\mathrm{MH}, \mathrm{LD}, \mathrm{SF}, \mathrm{DC}$, $\mathrm{MC}, \mathrm{BA}, \mathrm{BM}$ performed research. $\mathrm{MB}$ analyzed data. $\mathrm{MH}$ and $\mathrm{AB}$ wrote the paper. All authors read and approved the final manuscript.

\section{Acknowledgements}

This work was supported by research grants from CARIPLO Foundation (2007-5469), Italian Ministry of University and Scientific Research (MIUR), PRIN2007-2S2HT8, and National Institute of Environmental Health Sciences (ESOI5I72-0I), Associazione Italiana per la Ricerca sul Cancro (AIRC-60I6).

\section{References}

I. Chan SW, Blackburn EH: New ways not to make ends meet: telomerase, DNA damage proteins and heterochromatin. Oncogene 2002, 2 I:553-563.

2. von Zglinicki T: Oxidative stress shortens telomeres. Trends Biochem Sci 2002, 27:339-344.

3. Epel ES, Blackburn EH, Lin J, Dhabhar FS, Adler NE, Morrow JD, Cawthon RM: Accelerated telomere shortening in response to life stress. Proc Natl Acad Sci USA 2004, 101:17312-17315.

4. Valdes AM, Andrew T, Gardner JP, Kimura M, Oelsner E, Cherkas LF, Aviv A, Spector TD: Obesity, cigarette smoking, and telomere length in women. Lancet 2005, 366:662-664.

5. Harley $C B$, Futcher $A B$, Greider $C W$ : Telomeres shorten during ageing of human fibroblasts. Nature 1990, 345:458-460.

6. Richter T, von Zglinicki T: A continuous correlation between oxidative stress and telomere shortening in fibroblasts. Exp Gerontol 2007, 42:1039-1042.

7. Aviv A: Telomeres and human aging: facts and fibs. Sci Aging Knowledge Environ 2004, 2004:pe43.

8. Cawthon RM, Smith KR, O'Brien E, Sivatchenko A, Kerber RA: Association between telomere length in blood and mortality in people aged 60 years or older. Lancet 2003, 36 I:393-395.

9. Kimura M, Hjelmborg JV, Gardner JP, Bathum L, Brimacombe M, Lu $X$, Christiansen L, Vaupel JW, Aviv A, Christensen K: Telomere length and mortality: a study of leukocytes in elderly Danish twins. Am J Epidemiol 2008, 167:799-806.

10. Oikawa S, Kawanishi S: Site-specific DNA damage at GGG sequence by oxidative stress may accelerate telomere shortening. FEBS Lett 1999, 453:365-368.

II. Bakaysa SL, Mucci LA, Slagboom PE, Boomsma DI, McClearn GE Johansson B, Pedersen NL: Telomere length predicts survival independent of genetic influences. Aging Cell 2007, 6:769-774.

12. Brouilette S, Singh RK, Thompson JR, Goodall AH, Samani NJ: White cell telomere length and risk of premature myocardial infarction. Arterioscler Thromb Vasc Biol 2003, 23:842-846.

13. Fitzpatrick AL, Kronmal RA, Gardner JP, Psaty BM, Jenny NS, Tracy RP, Walston J, Kimura M, Aviv A: Leukocyte telomere length and cardiovascular disease in the cardiovascular health study. Am Epidemiol 2007, 165: |4-21.

14. Samani NJ, Boultby R, Butler R, Thompson JR, Goodall AH: Telomere shortening in atherosclerosis. Lancet 200I, 358:472-473.
15. Harst $P$ van der, Steege $G$ van der, de Boer RA, Voors AA, Hall AS, Mulder MJ, van Gilst WH, van Veldhuisen DJ: Telomere length of circulating leukocytes is decreased in patients with chronic heart failure. I Am Coll Cardiol 2007, 49: |459-| 464

16. Demissie S, Levy D, Benjamin EJ, Cupples LA, Gardner JP, Herbert A, Kimura M, Larson MG, Meigs JB, Keaney JF, et al.: Insulin resistance, oxidative stress, hypertension, and leukocyte telomere length in men from the Framingham Heart Study. Aging Cell 2006, 5:325-330.

17. Wu X, Amos Cl, Zhu Y, Zhao H, Grossman BH, Shay JW, Luo S, Hong WK, Spitz MR: Telomere dysfunction: a potential cancer predisposition factor. I Natl Cancer Inst 2003, 95:121 I-1218.

18. Peters A, von Klot S, Heier M, Trentinaglia I, Hormann A, Wichmann $\mathrm{HE}$, Lowel $\mathrm{H}$ : Exposure to traffic and the onset of myocardial infarction. N Engl J Med 2004, 35 I: I721-1730.

19. Hoffmann B, Moebus S, Mohlenkamp S, Stang A, Lehmann N, Dragano N, Schmermund A, Memmesheimer M, Mann K, Erbel R, et al.: Residential exposure to traffic is associated with coronary atherosclerosis. Circulation 2007, I I 6:489-496.

20. Nie J, Beyea J, Bonner MR, Han D, Vena JE, Rogerson P, Vito D, Muti $P$, Trevisan $M$, Edge $S B$, et al.: Exposure to traffic emissions throughout life and risk of breast cancer: the Western New York Exposures and Breast Cancer (WEB) study. Cancer Causes Control 2007, I 8:947-955.

21. Schwartz J: Long-term effects of exposure to particulate air pollution. Clin Occup Environ Med 2006, 5:837-848.

22. Chuang KJ, Chan CC, Su TC, Lee CT, Tang CS: The effect of urban air pollution on inflammation, oxidative stress, coagulation, and autonomic dysfunction in young adults. Am J Respir Crit Care Med 2007, I 76:370-376.

23. Rhoden CR, Lawrence J, Godleski J], Gonzalez-Flecha B: N-acetylcysteine prevents lung inflammation after short-term inhalation exposure to concentrated ambient particles. Toxicol Sci 2004, 79:296-303.

24. Peters A, Frohlich M, Doring A, Immervoll T, Wichmann HE, Hutchinson WL, Pepys MB, Koenig W: Particulate air pollution is associated with an acute phase response in men; results from the MONICA-Augsburg Study. Eur Heart J 200 I, 22: I I 98-I 204.

25. Adar SD, Adamkiewicz G, Gold DR, Schwartz J, Coull BA, Suh H: Ambient and microenvironmental particles and exhaled nitric oxide before and after a group bus trip. Environ Health Perspect 2007, I | 5:507-5 I2.

26. Violante FS, Barbieri A, Curti S, Sanguinetti G, Graziosi F, Mattioli S: Urban atmospheric pollution: personal exposure versus fixed monitoring station measurements. Chemosphere 2006, 64: I722-1729.

27. Cawthon RM: Telomere measurement by quantitative PCR. Nucleic Acids Res 2002, 30:e47.

28. McGrath M, Wong JY, Michaud D, Hunter DJ, De Vivo I: Telomere length, cigarette smoking, and bladder cancer risk in men and women. Cancer Epidemiol Biomarkers Prev 2007, 16:81 5-819.

29. Risom L, Moller P, Loft S: Oxidative stress-induced DNA damage by particulate air pollution. Mutat Res 2005, 592:1।9-137.

30. Moller P, Folkmann JK, Forchhammer L, Brauner EV, Danielsen PH, Risom L, Loft S: Air pollution, oxidative damage to DNA, and carcinogenesis. Cancer Lett 2008, 266:84-97.

31. Avogbe PH, Ayi-Fanou L, Autrup H, Loft S, Fayomi B, Sanni A, Vinzents $P$, Moller $P$ : Ultrafine particulate matter and highlevel benzene urban air pollution in relation to oxidative DNA damage. Carcinogenesis 2005, 26:613-620.

32. Lai CH, Liou SH, Lin HC, Shih TS, Tsai PJ, Chen JS, Yang T, Jaakkola JJ, Strickland PT: Exposure to traffic exhausts and oxidative DNA damage. Occup Environ Med 2005, 62:216-222.

33. Houben JM, Moonen HJ, van Schooten FJ, Hageman GJ: Telomere length assessment: biomarker of chronic oxidative stress? Free Radic Biol Med 2008, 44:235-246.

34. Serra V, von Zglinicki T, Lorenz M, Saretzki G: Extracellular superoxide dismutase is a major antioxidant in human fibroblasts and slows telomere shortening. I Biol Chem 2003, 278:6824-6830.

35. Brouilette SW, Moore JS, McMahon AD, Thompson JR, Ford I, Shepherd J, Packard C], Samani NJ: Telomere length, risk of coronary heart disease, and statin treatment in the West of Scotland Primary Prevention Study: a nested case-control study. Lancet 2007, 369:107-1/4. 
36. Minamino $\mathrm{T}$, Miyauchi $\mathrm{H}$, Yoshida $\mathrm{T}$, Ishida $\mathrm{Y}$, Yoshida $\mathrm{H}$, Komuro I: Endothelial cell senescence in human atherosclerosis: role of telomere in endothelial dysfunction. Circulation 2002, 105:154I-I544.

37. Bailey SM, Murnane JP: Telomeres, chromosome instability and cancer. Nucleic Acids Res 2006, 34:2408-24I7.

38. Bono R, Scursatone E, Schiliro T, Gilli G: Ambient air levels and occupational exposure to benzene, toluene, and xylenes in northwestern Italy. J Toxicol Environ Health A 2003, 66:5 I9-53I.

39. Kovacic P, Somanathan R: Ototoxicity and noise trauma: electron transfer, reactive oxygen species, cell signaling, electrical effects, and protection by antioxidants: practical medical aspects. Med Hypotheses 2008, 70:9|4-923.

40. Cherkas LF, Hunkin JL, Kato BS, Richards JB, Gardner JP, Surdulescu GL, Kimura M, Lu X, Spector TD, Aviv A: The association between physical activity in leisure time and leukocyte telomere length. Arch Intern Med 2008, 168:154-158.

Publish with Bio Med Central and every scientist can read your work free of charge

"BioMed Central will be the most significant development for disseminating the results of biomedical research in our lifetime. "

Sir Paul Nurse, Cancer Research UK

Your research papers will be:

- available free of charge to the entire biomedical community

- peer reviewed and published immediately upon acceptance

- cited in PubMed and archived on PubMed Central

- yours - you keep the copyright

Submit your manuscript here:

http://www.biomedcentral.com/info/publishing_adv.asp 